\title{
The Role of Wali Nanggroe Institution to Realize Peace in the Asymmetric Decentralization: the Case of Indonesia
}

\author{
Delfi Suganda; ${ }^{1}$ Retno Saraswati; ${ }^{2}$ Nabitatus Sa' ${ }^{\prime} d^{2}{ }^{2}$
}

${ }^{1}$ Doctoral Students Faculty of Law Universitas Diponegoro, Lecture of Islamic State Ar-Raniry University; ${ }^{2}$ Lecture Faculty of Law, Universitas Diponegoro

Corresponding author's email: delfi.suganda@ar-raniry.ac.id

\begin{tabular}{l}
\hline Article Information \\
\hline Submitted : August 28, 2021 \\
Reviewed : October 14, 2021 \\
Revised : November 15, 2021 \\
Accepted : December 13, 2021 \\
Keywords : \\
asymmetric decentralization; \\
international peace; \\
Wali Nanggroe Institution \\
DoI: https:/ / doi. \\
org/10.20961/yustisia. \\
v10i3.54705
\end{tabular}

Abstract
Aceh is a unique area in Indonesia based on Law Number 11 of
2006 concerning the Government of Aceh. One of its features
is the establishment of the Wali Nanggroe Institution which is
the highest customary institution that aims to maintain peace in
Aceh and participate in the world peace process. It is unique in
the Indonesian constitutional system because its officers are for-
mer combatants of the Free Aceh Movement. This study would
like to examine the opportunities and role of the Wali Nanggroe
Institution in realizing peace domestically and globally. There
are several opportunities for the Wali Nanggroe Institution in
peace efforts in a conflicted country; among others, the Wali
Nanggroe Institution can carry out the function of peace at the
local, national and international levels. It can apply due to the
legitimacy of laws and regulations, support from local political
parties that dominate Aceh's parliament, and good relations with
several foreign countries, such as the "Moro" separatist group
from the Philippines had studied with Wali Nanggroe how the
peace process from civil war can be realized.

\section{Introduction}

The 1945 Constitution is the highest law in the Indonesian legislative system, irrespective of whether the regulations are general, not detailed. More comprehensive policies are contained in the subordinating legislation, and the mandate regarding the existence of particular regions in Article 18B is stated as follows:

"The state recognizes and respects special regional government units as regulated by $\left.l a w^{* *}\right) . "$ 
These regional policies are further translated into various rules and regulations tailored to their needs.

The Aceh Province is one of such regions, which was once regulated by some given laws enacted by the central government. The first is Law Number 44 of 1999 concerning the Host of Privileges of the Province of Special Region of Aceh. The second is Law Number 18 of 2001 concerning Special Autonomy for the Special Region of Aceh, such as the Province of Nanggroe Aceh Darussalam. The third is the latest legislation regarding certain privileges, namely Law Number 11 of 2006 concerning the Aceh Government. This policy is a translation of the Memorandum of Understanding between the Free Aceh Movement (GAM) and the Government of Indonesia. Some of the points are interesting to examine, one of which is the regulation regarding the Wali Nanggroe Institution.

Meanwhile, the points that constitute Law Number 11 of 2006 concerning the Aceh Government are also contained in the 2005 Helskiny MoU in Finland mediated by the Crisis Management Initiative (CMI) Marti Ahtisaari Center (CMI, 2012; Ichal Supriadi, 2006). The regulation concerning the Wali Nanggroe Institution stated in Law Number 11 of 2006 is also mentioned in Chapter XII Articles 96 and 97.

“According to Article 96 (1), Wali Nanggroe Institution is a customary leadership perceived as an independent community unifier, authorized to foster and supervise the implementation of traditional institutions and customs, including awarding titles or degrees during ceremonies. (2) Wali Nanggroe Institution, referred to in paragraph (1), is not regarded as a political or government organization in Aceh. (3) As mentioned in paragraph (1), this institute is led by an independent Wali Nanggroe. (4) Further provisions regarding the candidate's requirements, electoral procedures, participants, office term, as well as other protocols, and finances are regulated by Aceh Qanun (local law). As regulated in article 97, this institution has the right to grant honorary or customary degrees to individuals or organizations, both home and abroad."

To implement the regulations mandated by Law Number 11 of 2006, in 2012, the Government and Provincial Parliament of Aceh jointly ratified Qanun Number 8 of 2012 concerning the Wali Nanggroe Institution.

Its duties, functions, and authorities were regulated in Qanun Number 8 of 2012. As stated in Article 29 letter (h), one of the duties is to cooperate with various parties both home and abroad regarding the civilization advancement in this region. In letter ( $\mathrm{j})$, this institute is responsible for maintaining and participating in local and international peace settlement processes. Furthermore, letter (l) involves the appointment or dismissal of customary representatives abroad.

\footnotetext{
370 Yustisia Volume 10 Number 3 (December 2021) The Role of Wali Nanggroe Institution to...
} 
The institution's functions are regulated in Article 30; meanwhile, letter (k) is related to foreign affairs concerning the cooperation of various parties both home and abroad for the advancement of Aceh civilization. Letter $(\mathrm{m})$ regulates the implementation and participation in the local and international peace settlement processes. Moreover, Article 31 concerning foreign affairs is regulated in letter $(\mathrm{g})$ regarding cooperating with foreign institutions or agencies.

The relationship between the Wali Nanggroe Institution and the Aceh government is different from the constitutional research, especially decentralization in Indonesia. However, this connection is not explicitly mentioned, although there is an affirmation regarding its independence. It is interesting to examine the explanation as mention because the Wali Nanggroe Institution is a regional organization in which the leader, namely Wali Nanggroe, was a former Free Aceh Movement (GAM) combatant that once served as the Tuha Peut and has also held important positions in the Local Party. Conversely, the mandated laws and regulations offer extraordinary authority regarding the functions of local, national, and international peace settlement processes (CMI, 2012).

Several previous studies have been carried out on the Wali Nanggroe Institution, including those reviewed by Dahlan A. Rahman and Nuriman Abdullah. The article entitled Dynamics and Prospect of Wali Nanggroe Institution Post-Conflict in Aceh: Analysis of Policy and Educational Development, reported that the dynamics of this organization are not only limited to political or legal issues; rather, cited above also strengthens and improves the potential of Aceh's culture and customs (Rahman \& Abdullah, 2018). This research focuses on the involvement and role of the Wali Nanggroe Institution in developing the educational sector in Aceh.

Similarly, the article written by Arif Akbar stated that this institution is independent, which indicates that it is impartial in handling issues involving certain groups in Aceh. Naturally, as a traditional institution, it also involves social leadership. According to this research, Wali Nanggroe is transformed into an institute for Local Strong Men. Subsequently, it focuses more on the relationship between the Aceh Party and Malik Mahmud as the organization's leader. This is due to the support of the Free Aceh Movement (GAM), where Malik Mahmud was a former official (Akbar, 2019).

The subsequent research was entitled "Wali Nanggroe in Aceh: Is he the Real King or the Fake One? A Political Review." In terms of content, the article focused on the electoral pattern for the leadership position. Interestingly, for a legal state, like Indonesia, election for public offices needs to reflect the principles of democracy, even at the regional level, and the Wali Nanggroe position is no exception. Therefore, it was emphasized that the electoral process is left to the people of Aceh (Badri Hasan Sulaiman, Zahlul Pasha Karim, Khairani Binti Mukdin, Muslim Abdullah Ahmad, 2020).

The three studies earlier mentioned explained the Wali Nanggroe Institution. These literature reviews are different, since they focus on the institute's function in realizing peace internationally and implementing special autonomy in Aceh. 


\section{Research Methods}

This doctrinal research focused on law books (Hakim, 2016; Sonata, 2014), which consists of legal inventory, principles, the concrete case, analysis of lawful systematic, and synchronization levels, as well as comparative, legislative history (Benuf \& Azhar, 2020; Simatupang, 2011). These are also the primary means of deductive logic to build a favorable legal system (Sulaiman, 2018). This research adopted a statutory approach, and data were collected by reviewing legal documents, especially laws and regulations, and journals found on the internet. Interviews were limited to the process of enacting policies relating to the research object.

\section{Research Result and Discussion}

A. The Opportunity for the Wali Nanggroe Institution to Carry out the Function of Peace Embodiment in Implementing Special Autonomy in Aceh

The principle of legal preference points to both the enforced preferred law and the ignored one. Agustina (2015) stated that an event is related to the violation of several regulations. This research adopted the theory of Lex Specialis Derogat Lex Generalis, where special rules derogate the general ones (Irfani, 2020). These norms have a more concrete and specific regulatory scope, enabling them to partially derogate the general legal provisions ( 2010).

Implementing an autonomous community requires the granting of a particular authority to realize and manage the region's welfare. Particular Autonomy Theory is an aspect of legal science closely related to the implementation of regional government in Indonesia as mandated in Article 18 of the 1945 Constitution. This state authorizes the approval of special autonomy in several regions, including Aceh Province.

This was implemented to restore the economy, political status as well as realize sustainable legal development; besides, it is perceived as a solution in terms of maintaining state integrity (Suharyo, 2018). The unique authority was then led by the Aceh province; during the process, several independent institutions were established to realize democratic expectations (Efendi, 2014), including fair and prosperous welfare (Aziz et al., 2019). Meanwhile, several historically, politically, and socio-culturally criteria are involved in granting special autonomy to Aceh. (Dunggio \& Jasin, 2019)

As earlier mentioned, decentralization was implemented to accelerate the state's goals to achieve prosperity through an effective local government (Sukirno, 2015). The special autonomy implemented in Aceh is different from other autonomous regions in terms of regulations and distinctive institutions (Aziz et al., 2019). This also attracts several limitations, one of which is executing foreign relations as a national matter (uusni Jalil, T. Ahmad Yani, 2010; Yoesoef, 2004). Based on the earlier mentioned theory, this research discusses the 
limitations that turned out as excellent opportunities for the Wali Nanggroe Institution to realize peace.

The controversial Wali Nanggroe Institution is inseparable from the political contestation in Aceh, especially after the existence of the local parties. Likewise, issues concerning the elites are also related to this institution, thereby belittling its function and role and creating a general impression of the excessive power given to Wali Nanggroe.

Paragraph 4 (Four) of the Preamble in the 1945 Constitution states that "Subsequently, to form a government of the state of Indonesia responsible for protecting its citizens, and their lands that have been struggled for, as well as to improve public welfare, and awareness towards the establishment of a world order based on freedom, perpetual peace, and social justice, thereby, leading to the development of a sovereign state based on the belief in the One and Only God, just and civilized humanity, unity, and democratic life led by wise deliberation of the people's representatives."

The preamble indicates that Indonesia is unavoidably relevant in realizing world peace. Presently, special autonomy and democracy need to be implemented in the Wali Nanggroe Institution, located in the territory of the Aceh province. It was also part of realizing peace between the Free Aceh Movement (GAM) and the Indonesia Government.

Judging from the legal aspect, Wali Nanggroe Institution is based on Article 18 of the 1945 Constitution, where Chapter VI regulates Regional Government and Paragraph (1) affirms the following.

"The Unitary State of the Republic of Indonesia is divided into provincial regions, which are further divided into regencies and cities, where each has a regional government, regulated by law **)." (1945 Constitution)

Paragraph (2) confirms the following

"Provincial, regency, and city-regional governments regulate and manage their affairs according to the principles of autonomy and co-administration.

**)"(1945 Constitution)

Regulations on particular regions arealso mentioned in the 1945 Constitution, precisely in Article 18B Paragraph (1), which confirms that

"The state recognizes and respects special regional government units that are also regulated by law**)"(1945 Constitution)

According to Article 18B Paragraph (2):

"The state recognizes and respects customary law units and their traditional obligations as long as they monitor community development and the principles of the Unitary State of the Republic of Indonesia. $\left.{ }^{* *}\right)^{\prime \prime}(1945$ Constitution) 
RegardingtheIndonesianconstitutionalhistory, asymmetric decentralization, namely Desentralisatie Wet 1903, was implemented during the Dutch East Indies era. Interestingly, it was divided into two groups, Zelfbesturende landschappen and volkgemeenschappen, perceived as regional units with a particular government. Based on the practical aspect (current practice), asymmetric decentralization was implemented in the Special Region of Aceh, the Special Capital Region of Jakarta, the Special Region of Yogyakarta, the Special Autonomy of Papua, West Papua, the Batam Region, and the borders of North Kalimantan. Various reasons were then taken into considerations in terms of determining the privileges and specificities of these areas, including the unresolved conflicting factors between the regional and central government and the increasing demand for separatism to secede to an independent state, recognizing the Special Capital Region of Jakarta (DKI Jakarta) as the state capital. These specific historical and cultural reasons led to the need for borders to get special treatment considering their role as territorial boundaries with neighboring states and as a Center for economic development. (Susila Wibawa, 2019)

At this empirical stage, there was a shift in the 1945 Constitution which is referred to as thehighestfundamental law, where Article18(Proclamation-Decree) provides the following interpretations Government (Central), Provincial Large (both of which are Special, Autonomous, Administrative), Small and Smaller Regional Government Provinces (both special, Autonomous, Administrative). Meanwhile, the amended Article 18 provides interpretation, Central, Provincial, Regency, and City Regional Governments. The 1945 Constitution (Amendment) confirms the mechanism for the delegation of authority "attributively stated" in its rules, namely 1) Regional governments (provinces, regencies, cities) are given the right to autonomy in terms of regulating and managing their households. 2) there is a division of power (authority) between the central, provincial, and regional governments. 3) the implementation of laws and regulations at the regional level. (Gadjong, 2011)

The recognition of particular regions and their regulations are contained in the constitution and the privileges of Aceh. Law Number 11 of 2006 concerning the Aceh Government became the legal basis for the Wali Nanggroe Institution formation. Article 96 Paragraph (4) confirms that every issue concerning this organization is regulated in the Aceh Qanun. (Law Number 11 of 2006 concerning the Aceh Government, 2006). This includes explicitly detailed authorities regarding the work and governance of this institution (Aceh Qanun Number 8 of 2012 concerning the Wali Nanggroe Institution, 2012).

Over time, the Aceh Qanun Number 8 of 2012 concerning the Wali Nanggroe Institution has changed. The first amendment was made in 2013, due to the evaluation made by the Minister of Home Affairs, which led to the enactment of a newly legal product (Aceh Qanun Number 9 of 2013 concerning Amendments 
to Aceh Qanun Number 8 of 2012 concerning the Wali Nanggroe Institution, 2013). After six years, there was another change, namely the second amendment (Aceh Qanun Number 10 of 2019 concerning the Second Amendment to Aceh Qanun Number 8 of 2012 concerning the Nanggroe Wali Institution, 2019).

Deviating from the earlier mentioned laws and regulations, the Wali Nanggroe Institution is a legal institute recognized by the state. It is highly relevant in maintaining and realizing the local, national, and international peace settlement process. This procedure is not explicitly stated in the local law or qanun. However, there are policies regarding the cooperation of the Aceh Government with foreign agencies or institutions as stipulated in the Presidential Regulation of Indonesia (Presidential Regulation of Indonesia Number 11 of $\underline{2010}$ concerning Cooperation Aceh Government with Institutions or Agencies Abroad, 2010).

Since independence, Aceh had played an essential role as one of the regions that the Dutch could not conquer. Therefore, it was made an autonomous administrative province and is no longer part of the North Sumatra since 1956 (Law Number 24 of 1956 concerning the Establishment of the Autonomous Region of Aceh Province and Amendments on the Regulations for the Establishment of North Sumatra Province, 1956). The lengthy establishment process hurt the Aceh province, which then led to the emergence of rebellious groups. (Zainal, $\underline{2016)}$

In the 70s, Muhammad Hasan Di Tiro chaired the Free Aceh Movement (GAM) group, demanding autonomy, and named this movement the "successor state." This was aimed to ensure the Aceh Kingdom was not subjected to invaders (Abdullah, 2016). Nazaruddin Syamsuddin and Kurnia Jayanti stated that the conflict in 1976 started when Hasan Tiro declared the GAM in Pidie (Jayanti, 2013). Hasan Di Tiro was also the Wali Nanggroe institution's leader and influenced GAM both home and abroad. Therefore, at that time, this group had role models or strong figures in fighting for their rights.

Generally, Wali Nanggroe does not have a meaningful history, although the zealous spirit has always been there, especially in the GAM former combatants. However, there are only a few pieces of literatures regarding this effect, especially after the social (Aceh conflict) and natural disasters (earthquake and tsunami). Therefore, there are not many publications related to the Wali Nanggroe Institute. Several findings are used as comparisons and to differentiate between the present and previous analyses to obtain the originality of this research.

Some literature reported that Wali Nanggroe is an influential figure in Aceh (Akbar, 2019), especially in the current era of special autonomy. This is also used to build a better province, mainly to set an example regarding peace to the world. The realization of peace in this province is due to a lengthy effort between 
the Government of Indonesia and GAM. This led to special autonomy rights, which differentiated Aceh from other provinces. This is called Asymmetric decentralization, and the Wali Nanggroe Institution is one of such differences. (Sanur, 2020)

Furthermore, this controversy has even emerged among local political actors, the Acehnese, and the academic sector (Muhammad Ridwan, Fauzi, Jumadil Saputra, Yahaya Ibrahim, 2019). According to Yunandar et al. (2014), these comprised supportive and refusal groups. Interestingly, those that constitute the refusal groups believe that the institution does not represent all ethnicities in Aceh and even can disintegrate because they believed it was established to benefit a particular people.

Political identity has been attached to the Wali Nanggroe Institution since its establishment, which is also considered not to run concurrently with the duties of the state. This is because the regulations have not been adequately implemented, thereby influencing the rejection of this organization in Aceh.

As earlier mentioned, the Wali Nanggroe Institution is a unifying establishment for the Acehnese, responsible for maintaining peace, particularly locally, which has been realized since 2005. However, this also includes nationally and internationally. This institution has juridical opportunities mandated by specific regulations. It also aids in achieving and implementing the mandate of Law No. 11 of 2006 concerning the Aceh Government and Qanun No. 8 of 2012 concerning the Wali Nanggroe Institution.

The peace agreement between the GAM and the Government of Indonesia has been discussed for a long while, and President Abdurrahman Wahid initiated in January 2000 to resolve the conflict in Aceh. However, this discussion was resumed in 2002 (Ichal Supriadi, 2006). Subsequently, in 2004, it was renegotiated by the newly elected President and Vice President of Indonesia, namely Susilo Bambang Yudhoyono and Jusuf Kalla (Aspinall, 2005). The signing of the Helsinki MoU in Finland positively impacted Aceh Province, especially the former GAM combatants (Aspinall, 2009). Since then, special rights or authorities have increased, such as the existence of several Local Parties which dominate the Provincial Parliament.

Fortunately, since its being regulated in Law No. 11 of 2006 concerning the Aceh Government, local parties have become unique concerns in terms of realizing the implementation of certain privileges. Article 1 number 14 of Law Number 11 of 2006 concerning the Aceh Government defines a local party as a political organization formed by a group of citizens voluntarily domiciled in the province based on the same will and ideals to fight for the common interests of its members, the society, nation, and state at large. This is realized during Aceh 
Provincial/Regional Parliament, Governor/Deputy Governor, regent/deputy regent, and mayor/deputy mayor election.

\section{B. The National Parties Become Sterile Amid the Diversity of a Pluralistic Society and the Positive Impact of the Local Political Parties}

The positive impact of these local political parties is based on the fact that they have the right to participate in the gubernatorial and legislative electoral process. Irwandi Yusuf and Muhammad Nazar won the first governorship election, which marked these political parties' victory (Group, 2007). During the next election held in 2011, there was a severe battle between 2 significant factions of the former GAM combatants, namely the incumbent governor Irwandi Yusuf and the Aceh Party (Group, 2011). This indicated that democracy was starting to develop, even though there was violence during the gubernatorial election in 2011 (International Crisis Group, 2012).

In terms of objectives, the local political parties are generally categorized into 3: 1) Those that protect and promote economic, social, and cultural rights, as well as the language and education of certain minority groups. 2) those that want autonomy for its region or enforce and enhance autonomous rights. 3) those that explicitly fight for the independence of their territory and form a new state (Jafar AW, 2016).

The emergence of these parties is also driven by the inability of the national ones to represent the interests of the people. Apart from political factors and the signing of the Helsinki MoU, the local legislators have taken no serious action regarding lending their voice in the Central Government. This is similar to the course of Indonesian history. National parties have become sterile amid the diversity of a pluralistic society, which led to the emanation of an alternative (Muttaqin, 2019). The emergence of various local and national political parties with different authorities is not new, amid the ongoing democratic movement in Indonesia (Karsayuda, 2010).

In Aceh, local political parties are monitored by Government Regulations (Government Regulation Number 20 of 2007 concerning Local Political Parties in Aceh, 2007). Interestingly, both local and national political parties also carry out similar functions. In the Indonesian party system, the law authorized these to gain political power and fight for their rights according to constitutional patterns. However, they are only entitled to limit political positions in the Aceh region. According to Jafar AW (2016), their establishment is within the specific framework developed by the government. Therefore, their vision and organization mission statements accommodate local Acehnese and religious values. 
In 2009, the Aceh legislative election became a considerable momentum due to the Government Regulation No. 20 of 2007 concerning Local Political Parties, which led to their formation. Meanwhile, in 2008, 13 parties were registered under the Kemenkunham (Ministry of Law and Human Rights), this includes the Aceh People's Party, Aceh Muslim Unity Party (PPMA), Darussalam Party, GAM Party, Aceh Beusaboh That, and Taqwa (Gab that) Generation Party, Serambi Persada Nusantara United Party (PSPNS), Aceh People's Alliance for Women Party (PARA), Aceh Meudaulat Party (PAM), Aceh Local Party (PLA), Aceh Sovereign Party (PDA) (PDA has changed its name three times, first was the Aceh Sovereign Party, which was later changed to Aceh Peace Party and finally Aceh Regional Party), Aceh Prosperous Muslim Party (PAAS), SIRA Party, and United Aceh Party (PBA) (news.detik.com, 2008).

Of these parties, only the Aceh Party (PA) had 33 seats, while the Aceh Sovereign Party (PDA) had just 1 (Koran.tempo.co, 2014). In the 2014 Aceh legislative elections, only 3 (three) local parties, namely the Aceh Party (PA), Aceh Sovereign Party (PDA), and the Aceh National Party (PNA), participated in the process (KIP, 2013). In 2014, the Aceh Party (PA) was dominated by 29 seats that were reduced compared to the 2009 Legislative Election. Another local party, the Aceh Sovereign Party (PDA), won 1 seat while the newcomer perceived as the rivalry of the Aceh Party (PA), and the Aceh National Party won 3 seats (Aceh.tribunnews.com, 2014; Nurhasim, 2012)

Figure1.GraphofLocalPoliticalPartiesin AcehLegislativeElectionfrom2009to2014

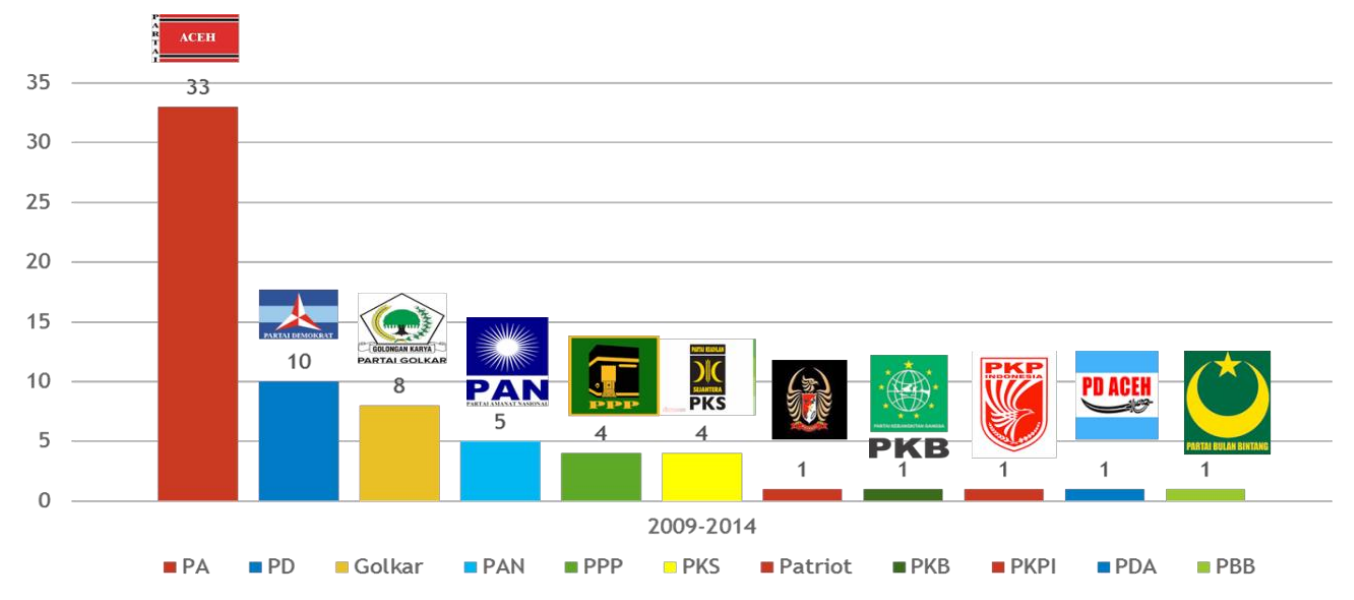

During the 2009 and 2014 legislative elections, the Aceh Party was not only dominant, but it was also perceived as a transformation of the Free Aceh Movement (GAM) (Sahruddin, 2014). This means that the movement, which used to fight with weapons and guerrillas in the jungle, has transformed into a local political party advocating for peace. 
About Wali Nanggroe, Malik Mahmud, a former GAM figure during the conflict and Tuha Peut in the Aceh Party, held a dominant and highly influential elite position (Andriyani, 2017; Darwin, 2016). Nurhasim's interview with Zakarian Saman, the former GAM, Minister of Defense, stated that during the struggle period, the position of Hasan Tiro was considered the Wali Nanggroe by this group while Malik Mahmud became the leader of the GAM elite in consolidating and running this organization because Hasan Tiro was old (Nurhasim, 2009).

Interestingly, Aceh Qanun Number 8 of 2012 concerning the Wali Nanggroe Institution was periodically formed in the middle of the first legislative election after the 2005 Helsinky MoU. Additionally, His Excellency (PYM) Malik Mahmud Al Hayter was the first Wali Nanggroe after enacting this law. The data above shows a good relationship between His Excellency Malik Mahmud Al-Hayter and local parties in the 2009 to 2014 and 2014 to 2019 legislative elections. Therefore, most of the activities executed by Malik Mahmud AlHaytar were likely to support the legislation. This included both the national and international peace treaty in Aceh.

Since its establishment in 2012, the Wali Nanggroe Institution has been in the public spotlight, although its existence and urgency are still questionable. This is the outcome of the agreement merged into Law Number 11 of 2006 concerning the Aceh Government. The Wali Nanggroe Institution has become a topic of discussion because it is one of the oldest organizations in the province, and its primary function, is to maintain peace.

The presence of this institution also aids in harmonizing the interests of the Central and Local governments. According to His Excellency Malik Mahmud AlHayter, this organization is majorly responsible for the maintenance of peace, as well as providing input or opinions to the Aceh government and Ex-Combatants of the Free Aceh Movement (GAM) and also to the community in general because it unites all traditional identities (Rahman \& Abdullah, 2018). Malik further emphasized that these suggestions were directed to both horizontal and vertical institutions, namely the central government, the Indonesian National Army (TNI) and Police (POLRI), as well as members of the Indonesian National Armed Forces (Warsidi, 2019).

His Excellency Malik Mahmud Al-Hayter is certainly experienced in peacerelated issues, as reflected by the handshake with the Indonesian government during the Helsinky MoU negotiations in Finland. According to Maulana (2018), Malik Mahmud accompanied several personalities from Aceh (Maulana, 2018). These activists involved both men and women (Dialogue, 2011; Id.undp.org, 2014; Kemlu.go.id, 2021; Mediatorsbeyondborders.org, n.d.) 
These efforts aided in maintaining the peace that has been realized in Aceh. The meeting between His Excellency Malik Mahmud Al Haytar as Wali Nanggroe Aceh with the European Union and Brunei Darussalam Ambassadors to Indonesia during the Helsinky MoU negotiation was a manifestation of the excellent relationship existing between these foreign states (acehportal.com, 2021; Infoaceh.net, 2021; modusaceh. co, 2020) The European Union further inquired about the progress of peace in Aceh (Theacehpost.com, 2021).

This aimed to boost economic growth by attracting foreign investors (ajnn.net, 2019). Furthermore, the EU Ambassador also visited Meuligo Wali Nanggroe (Serambinews.com, 2020). Apart from good communication with the European Union, His Excellency also accepted the invitation from the United States Embassy and Consulates in Medan to celebrate the 70 years of bilateral relations between the two countries. Besides, the United States also has good relations with Aceh after the emergence of the social (conflicts) and natural disasters (the Aceh earthquake and tsunami) (Katibulwali.acehprov.go.id, 2019)

Apart from the relations with foreign parties, as earlier mentioned, other opportunities related to the peace mission in Aceh were also exploited. The mission is potentially realized because almost the whole world knows about it. Therefore, it is an inspiration in realizing peace in states with separatist groups, such as in the Philippines.

The peace mission between the GAM and the Indonesian government led to the conflict in the Philippines, such as the Moro Islamic Liberation Front (MILF) armed group in an insurgency. Chairman Al Haj Murat Ibrahim, and several otled thisher figures who came to Aceh to learn about the peace process realized 15 years ago (Aceh.tribunnews.com, 2018; Katibulwali acehprov.go.id, 2018; Tribunnews.com, 2018) precisely in 2015. Members of the Philippine Congress that visited Aceh stated that they wanted to learn about the peace process to resolve the religious conflict that occurred in the country (merdeka.com, 2015).

Besides creating peace in the cross-state sector, the involvement of the Wali Nanggroe Institution is needed. To achieve this, the organization becomes part of the peace effort in Papua. Subsequently, the armed criminal groups in this province need to learn from the peace mission in Aceh. This also boosted the hope of 70 Papuan students in Aceh because His Excellency once had good intentions for them (Acehmonitor.com, 2019). The establishment of the Papuan Student Association (HIMAPA) was due to several reasons, including to hear firsthand the peace process held in 2005 (dialeksis.com, 2019).

The process of realizing national peace by His Excellency Malik Mahmud Al Haytar as Wali Nanggroe Aceh was certainly not carried out without communicating with the central government; besides, several challenges were encountered. The interest in realizing peace on a local and national scale, even the involvement of the Wali Nanggroe Institution, also needs to be accompanied by the human resources in Aceh. 
This is based on several strong reasons, first is the involvement of numerous activists in realizing the peace negotiation process in Finland. Second is the involvement of several former officials of the GAM. Third, His Excellency Malik Mahmud Al-Hayter is also a motivator for peace in several conflicting states. Apart from the established relations, there are numerous helpful activities related to peace efforts in the world.

\section{Conclusion}

In conclusion, The peace will continue after the peace agreement because many Acehnese leaders, former GAM leaders, believe that the MOU can bring Aceh to a selfgovernment system through a peaceful and democratic process. In other words, the peace continues in tandem with the continuity of ideological movement in Aceh. There are several opportunities can be used by it to carry out the function of peace, among others, the first is strong support from local political parties because Wali Nanggroe is an "old man" in Aceh and it also dominate the Aceh parliament; Third, the activists in Aceh involved in the peace process, good relations between Wali Nanggroe and foreign countries or bodies, as well as Wali Nanggroe's own experience in the negotiation process with the Government of Indonesia to realize the understanding of the Helsinki MoU in Finland. The opportunity could have been mandated by the Wali Nanggroe Institution, part of the Republic of Indonesia, to realize world peace as mandated in the opening of the 1945 Constitution..

\section{Bibliography:}

\section{Journal Articles}

Abdullah, M. A. (2016). Kedudukan Wali Nanggroe Setelah Lahirnya Undang-Undang Pemerintahan Aceh. Kanun - Jurnal Ilmu Hukum, 18(2). https:/ / doi.org/10.24815/ kanun.v18i2.5925

Agustina, S. (2015). Implementasi Asas Lex Specialis Derogat Legi Generali dalam Sistem Peradilan Pidana. Jurnal Masalah-Masalah Hukum, 44(4). https://ejournal. undip.ac.id/index.php/mmh/article/view/11468/10227

Akbar, A. (2019). Malik Mahmud Legal Strongmen? Logos Journal, 2(1). https:/ / doi.org/ https:// doi.org/10.22219/logos.Vol2.No1.38-50

Andriyani, S. (2017). Gerakan Aceh Merdeka (GAM), Transformasi Politik Dari Gerakan Bersenjata Menjadi Partai Politik Lokal Aceh. Jurnal ISIP: Jurnal Ilmu Sosial Dan Ilmu Politik, 14(1). https:// doi.org/10.36451/j.isip.v14i1.32

Aspinall, E. (2005). The Helsinki Agreement : A More Promising Basis for Peace in Aceh? (Vol. 20). East-West Center Wahington.

Aspinall, E. (2009). Combatants to Contractors: The Political Economy of Peace in Aceh. Indonesia, 87(87), 1-34. 
Aziz, N. L. L., Zuhro, R. S., Cahyono, H., Suryani, D., Aulia, D., \& Maulana, Y. (2019). Model Pengelolaan Desentralisasi Asimetris dalam Konteks NKRI. P2Politik-LIPI. www.politik.lipi.go.id

Badri hasan Sulaiman, Zahlul Pasha Karim, Khairani Binti Mukdin, Muslem Abdullah Ahmad, M. S. A. (2020). Wali Nanggroe in Aceh: Is He the Real King or the Fake One? A Political Review. International Journal of Innovation, Creativity and Change, 13(10).

Benuf, K., \& Azhar, M. (2020). Metodologi Penelitian Hukum sebagai Instrumen Mengurai Permasalahan Hukum Kontemporer. Gema Keadilan, 7(1), 20-33.

CMI. (2012). Proyek Tindak Lanjut Proses Perdamaian Aceh.

Darwin, R. L. (2016). Institusionalisasi Partai Aceh : Patronase dan Konsolidasi dalam Transisi Demokrasi Pasca Konflik. Governnment:Jurnal Ilmu Pemerintahan, 9(2).

Dialogue, C. for H. (2011). Penciptaan Perdamaian di Asia dan Pasifik : Partisipasi, perspektif dan prioritas perempuan Women at the Peace Table Asia Pacific.

Dunggio, K. H., \& Jasin, J. (2019). Validitas Peraturan Daerah Yang Bernuansa Syariah Dalam Bingkai Otonomi Daerah. Law, Development E Justice Review, 2(2). https:/ / doi.org/10.14710/ldjr.v2i2.6204

Efendi. (2014). Kewenangan Pengelolaan Sumber Daya Alam Pada Era Otonomi Khusus Di Aceh. Yustisia Jurnal Hukum, 3(2). https:/ / doi.org/10.20961/yustisia.v3i2.11104

Gadjong, A. A. (2011). Analisis Filosofis Pemerintahan Daerah Dalam Pergantian (Perubahan) Kaidah Hukum Dasar Negara. Jurnal Hukum \& Pembangunan, 41(1). https:// doi.org/10.21143/jhp.vol41.no1.243

Group, I. C. (2007). Indonesia: how GAM won in Aceh. Asia Briefing, March 2007. http:/ / www.crisisgroup.org $/$ home $/$ index.cfm? $\mathrm{id}=4715 \& \mathrm{CFID}=24661599 \& \mathrm{CFTOK}$ $\mathrm{EN}=10248376$

Group, I. C. (2011). Update Briefing Indonesia: GAM vs GAM in the Aceh Elections. Asia Briefing, 123. http://www.crisisgroup.org/@0303/media/Files/asia/southeast-asia/indonesia/B123 Indonesia --- Gam vs Gam in the Aceh Elections.pdf

Hakim, M. H. (2016). Pergeseran Orientasi Penelitian Hukum dari Doktrinal Ke SosioLegal. Syariah Jurnal Hukum dan Pemikiran, 16(2). https://doi.org/http://dx.doi. org/10.18592/sy.v16i2.1031

Hiariej, E. O. S. (2021). Asas Lex Specialis Systematis dan Hukum Pidana Pajak. Jurnal Penelitian Hukum De Jure, 21(1). https:/ / doi.org/10.30641/dejure.2021.v21.1-12 
Husni Jalil, T. Ahmad Yani, M. D. Y. (2010). Implementasi Otonomi Khusus di Provinsi Aceh Berdasarkan Undang-Undang Nomor 11 Tahun 2006. Kanun: Jurnal Ilmu Hukum, 2(2). https:// doi.org/10.24815/kanun.v12i2.6295

Ichal Supriadi, S. S. H. (2006). Aceh: Balloting for Peace and Democracy PILKADA Nanggroe Aceh Darussalam (NAD) 2006 (Issue December). Asian Network for Free Elections (ANFREL).

Id.undp.org. (2014). A Sole Woman at the Negotiating Table for Peace | UNDP in Indonesia. https:// www.id.undp.org/content/indonesia/en/home/presscenter/ articles/2014/06/27/a-sole-woman-at-the-negotiating-table-for-peace.html

International Crisis Group. (2012). Indonesia : Averting Election Violence in Aceh. Asia Program Briefing, February, 1-12. www.crisisgroup.org

Irfani, N. (2020). Asas Lex Superior, Lex Specialis, dan Lex Posterior: Pemaknaan, Problematika, dan Penggunaannya dalam Penalaran dan Argumentasi Hukum. Legislasi Indonesia, 16(3). https:/ / doi.org/https:// doi.org/10.54629/jli.v17i3.711

Jafar AW, M. (2016). Asas Demokrasi dan Partai Politik Lokal Di Provinsi Aceh. Jurnal Ilmu Politik dan Pemerintahan, 2(1).

Jayanti, K. (2013). Konflik Vertikal Antara Gerakan Aceh Merdeka di Aceh dengan Pemerintah Pusat di Jakarta Tahun 1976-2005. Buletin Al-Turas, 19(1).

Kammerhofer, J. (2010). Uncertainty in International Law: A Kelsenian Perspective. Routledge.

Karsayuda, M. R. (2010). Partai Politik Lokal di Negara Kesatuan: Upaya Mewujudkan Otonomi Daerah di Bidang Politik. Jurnal Hukum, 17(4), 530-551. https:// doi. org/10.20885/iustum.vol17.iss4.art2

Maulana, R. (2018). Komunikasi Politik GAM-RI pada Perundingan Helsinki. Jurnal Studi Komunikasi (Indonesian Journal of Communications Studies), 2(3). https:// doi. org/10.25139/jsk.v2i3.1096

Muhammad Ridwan, Fauzi, Jumadil saputra, Yahaya Ibrahim, Z. M. (2019). Recognition of the Aceh kingdom system: Wali Nanggroe in Indonesia Republic system. Opción, 35(19).

Muttaqin, A. (2019). Demokrasi dan Sistem Kepartaian “Menimbang Partai Lokal di Indonesia. AlQisthas; Jurnal Hukum dan Politik, 10(1).

Nurhasim, M. (2009). Transformasi Politik Gerakan Aceh Merdeka (GAM ). Jurnal Penelitian Politik, 6(1), 85-98. http://ejournal.politik.lipi.go.id/index.php/jpp/ article/view/531/339 
Nurhasim, M. (2012). Dominasi Partai Aceh Pasca-MoU Helsinki Pendahuluan Tarik Ulur Partai Lokal di Meja. Jurnal Penelitian Politik LIPI, 9(2), 35-49. https:// doi. org/https://doi.org/10.14203/jpp.v9i2.229

Rahman, D. A., \& Abdullah, N. (2018). Dynamics and Prospect of Wali Nanggroe Institution Post-Conflict in Aceh: Analysis of Policy and Educational Development. In Proceeding of MICoMS (Vol. 1). https://doi.org/10.1108/978-1-78756-793-100021

Sahruddin. (2014). Partai Aceh dalam Transisi Demokrasi di Aceh Aceh(Party in the Transition of Democracy in Aceh). Jurnal Kajian Politik Dan Masalah Pembangunan, 10(1).

Sanur, D. (2020). Implementasi Kebijakan Otonomi Khusus di Aceh [Implementation of Special Autonomy Policies in Aceh]. Jurnal Politica Dinamika Masalah Politik Dalam Negeri Dan Hubungan Internasional, 11(1), 65-83. https:/ / doi.org/10.22212/ jp.v11i1.1580

Simatupang, T. H. (2011). Pemihakan dan Pemilihan Atas Penelitian Hukum Doktrinal dan Non Doktrinal. Forum Ilmiah, 8(1).

Sonata, D. L. (2014). Metode Penelitian Hukum Normatif dan Empiris: Karakteristik Khas Dari Metode Meneliti Hukum. Fiat Justisia Jurnal Ilmu Hukum, 8(1), 52.

Suharyo. (2018). Otonomi Khusus di Aceh dan Papua di Tengah Fenomena Korupsi, Suatu Strategi Penindakan Hukum. Jurnal Penelitian Hukum De Jure, 18(3). https:/ / doi.org/10.30641/dejure.2018.v18.305-318

Sukirno, D. K. (2015). Penerapan Desentralisasi Asimetris Dalam Penyelenggaraan Urusan Keistimewaan Daerah Istimewa Yogyakarta Sebagai Basis Otonomi bagi Terwujudnya Kesejahteraan Rakyat. Cakrawala Hukum, 11(1).

Sulaiman, S. (2018). Paradigma dalam Penelitian Hukum. Kanun Jurnal Ilmu Hukum, 20(2), 255-272. https://doi.org/10.24815/kanun.v20i2.10076

Susila Wibawa, K. C. (2019). Penegasan Politik Hukum Desentralisasi Asimetris dalam Rangka Menata Hubungan Pemerintah Pusat dengan Pemerintah Daerah di Indonesia. Administrative Law and Governance Journal, 2(3). https://doi. org/10.14710/alj.v2i3.400-412

Warsidi, A. (2019). Wali Nanggroe Pemimpin Adat Aceh. Sekretariat Lembaga Wali Nanggroe.

Yoesoef, A. Y. A. M. D. (2004). Qanun sebagai Peraturan Pelaksanaan Otonomi Khusus di Provinsi Nanggroe Aceh Darussalam. Jurnal Legislasi Indonesia, 1(3).

384 Yustisia Volume 10 Number 3 (December 2021)

The Role of Wali Nanggroe Institution to... 
Yunandar, M. A., Hasan, E., \& Abdullah, T. (2014). Pro Kontra Lembaga Wali Nanggroe dan Potensinya Terhadap Konflik Disintegrasi suku di Aceh. Seminar Nasional Riset Inovatif II.

Zainal,S. (2016). Transformasi Konflik Aceh dan Relasi Sosial-Politik di Era Desentralisasi. MASYARAKAT: Jurnal Sosiologi, 21(1). https://doi.org/10.7454/mjs.v21i1.4757

\section{Legal Documents}

KIP. (2013). Keputusan Komisi Independent Pemilihan Aceh Nomor 02 Tahun 2013 Tentang Penetapan Nomor Urut Partai Politik Lokal Sebagai Peserta Pemilu Anggota DPRA Dan DPRK Tahun 2014.

Peraturan Pemerintah Nomor 20 Tahun 2007 Tentang Partai Politik lokal di Aceh, (2007).

Peraturan Presiden Republik Indonesia Nomor 11 Tahun 2010 tentang Kerja Sama Pemerintah Aceh dengan Lembaga Atau Badan di Luar Negeri, (2010).

Qanun Aceh Nomor 10 Tahun 2019 Tentang Perubahan Kedua Atas Qanun Aceh Nomor 8 Tahun 2012 Tentang Lembaga Wali Nanggroe, (2019).

Qanun Aceh Nomor 8 Tahun 2012 tentang Lembaga Wali Nanggroe, (2012).

Qanun Aceh Nomor 9 Tahun 2013 tentang Perubahan Atas Qanun Aceh Nomor 8 Tahun 2012 Tentang Lembaga Wali Nanggroe, (2013).

Undang-Undang Dasar 1945, (1945).

Undang-Undang Nomor 11 Tahun 2006 tentang Pemerintahan Aceh, (2006).

Undang-Undang Republik Indonesia Nomor 24 Tahun 1956 Tentang Pembentukan Daerah Otonom Provinsi Aceh dan Perubahan Peraturan Pembentukan Provinsi Sumatra Utara, (1956).

\section{Book}

Warsidi, A. (2019). Wali Nanggroe Pemimpin Adat Aceh. Sekretariat Lembaga Wali Nanggroe.

\section{World Web Websites}

Aceh.tribunnews.com. (2014). PA Raih 29 Kursi DPRA. https://aceh.tribunnews. com/2014/04/27/pa-raih-29-kursi-dpra

Aceh.tribunnews.com. (2018). Wali Nanggroe Malik Mahmud Terima Kunjungan Puluhan Muslim Moro Filipina. https://aceh.tribunnews.com/2018/01/29/wali-nanggroemalik-mahmud-terima-kunjungan-puluhan-muslim-moro-filipina 
Acehmonitor.com. (2019). Bicarakan Perdamaian, Himpunan Mahasiswa Papua dan DPP SIGAP Ketemu Wali Nanggroe. https://acehmonitor.com/bicarakan-perdamaianhimpunan-mahasiswa-papua-dan-dpp-sigap-ketemu-wali-nanggroe/

acehportal.com. (2021). Konjen Malaysia Temui Wali Nanggroe, Bahas Lanjutan dan Agenda Kerjasama Baru. https://www.acehportal.com/news/konjen-malaysia-temuiwali-nanggroe-bahas-lanjutan-dan-agenda-kerjasama-baru/index.html

ajnn.net. (2019). Swedia dan Finlandia Punya Niat Berinvestasi di Aceh. https:/ / www.ajnn. net/news/swedia-dan-finlandia-punya-niat-berinvestasi-di-aceh/index.html

dialeksis.com. (2019). Mahasiswa Papua Bertemu Wali Nanggroe. https:/ / dialeksis.com/ aceh/mahasiswa-papua-bertemu-wali-nanggroe/

Id.undp.org. (2014). A Sole Woman at the Negotiating Table for Peace | UNDP in Indonesia. https:// www.id.undp.org/content/indonesia/en/home/presscenter / articles/2014/06/27/a-sole-woman-at-the-negotiating-table-for-peace.html

Infoaceh.net. (2021). Kunjungi Aceh, Sekretaris Politik Kedubes Kanada Temui Wali Nanggroe. https:/ / infoaceh.net/aceh/ kunjungi-aceh-sekretaris-politik-kedubes-kanadatemui-wali-nanggroe/

Katibulwali.acehprov.go.id. (2018). keurukon katibul wali | Moro Islamic Liberation Front (MILF) Temui Wali Nanggroe Aceh. https://katibulwali.acehprov.go.id/index. $\mathrm{php} /$ page/33/moro-islamic-liberation-front-mi

Katibulwali.acehprov.go.id.(2019). keurukon katibul wali | Press Release Protokol Dan Humas Keurukon Katibul Wali/ Sekretariat Lembaga Wali Nanggroe Aceh. https:/ / katibulwali. acehprov.go.id/index.php/news/read/2019/06/26/14/press-release-protokoldan-humas-keurukon-katibul-wali-sekretariat-lembaga-wali-nanggroe-aceh.html

Kemlu.go.id. (2021). Kemlu RI Terus Dorong Peran Perempuan Sebagai Negosiator Dan Mediator Perdamaian Di Asia Tenggara. https:/ / kemlu.go.id/portal/id/read/2605/ berita/kemlu-ri-terus-dorong-peran-perempuan-sebagai-negosiator-danmediator-perdamaian-di-asia-tenggara

Koran.tempo.co. (2014). Jumlah Kursi Partai Aceh Melorot. https:/ / koran.tempo.co/read/ nusa/342040/jumlah-kursi-partai-aceh-melorot

Mediatorsbeyondborders.org. (n.d.). Shadia Marhaban Southeast Asia Representative. Retrieved November 24, 2021, from https://mediatorsbeyondborders.org/bio/ shadia-marhaban-2/

merdeka.com. (2015). Perdamaian di Aceh jadi inspirasi Filipina selesaikan konflik agama. https:/ / www.merdeka.com/peristiwa/perdamaian-di-aceh-jadi-inspirasifilipina-selesaikan-konflik-agama.html 
modusaceh.co. (2020). Bahas MoU Helsinki, Wali Nanggroe Aceh dan Mualem "Gerilya" Temui Dubes Uni Eropa. https://modusaceh.co/news/bahas-mou-helsinki-walinanggroe-aceh-dan-mualem-gerilya-temui-dubes-uni-eropa/index.html

news.detik.com. (2008). 13 Partai Politik Lokal di Aceh Mulai Diverifikasi. https://news. detik.com/berita/d-901271/13-partai-politik-lokal-di-aceh-mulai-diverifikasi

Serambinews.com. (2020). Dubes Uni Eropa Bertemu Wali Nanggroe. https://aceh. tribunnews.com/2020/03/04/dubes-uni-eropa-bertemu-wali-nanggroe

Theacehpost.com. (2021). Uni Eropa Pertanyakan Perkembangan Aceh kepada Wali Nanggroe. https:/ / theacehpost.com/uni-eropa-pertanyakan-perkembangan-aceh-kepadawali-nanggroe/

Tribunnews.com. (2018). Anggota Kelompok bersenjata Muslim Filipina Bertemu Wali Nanggroe. https://www.tribunnews.com/regional/2018/01/30/anggota-kelompok-bersenjata-muslim-filipina-bertemu-wali-nanggroe 